\title{
Technical Barriers to Trade and China's Trade
}

\author{
Hong Gu \\ Shanghai University of International Business and Economics, Shanghai, China \\ Email: hgu010@163.com
}

How to cite this paper: $\mathrm{Gu}, \mathrm{H}$. (2017) Technical Barriers to Trade and China's Trade. Modern Economy, 8, 1045-1055. https://doi.org/10.4236/me.2017.88072

Received: July 21, 2017

Accepted: August 14, 2017

Published: August 17, 2017

Copyright (C 2017 by author and Scientific Research Publishing Inc. This work is licensed under the Creative Commons Attribution International License (CC BY 4.0).

http://creativecommons.org/licenses/by/4.0/

\begin{abstract}
China's foreign trade volume is growing due to the increasingly globalized economy and the improvement in China's international status. With China's accession to the WTO and the rapid expansion of foreign economic and trade and economic rise, technical barriers to trade are widely used as a measure. In recent years, many Chinese export enterprises have encountered some of the world's major developed countries. The impact of TBT reaches the ultrabillion dollars each year. Therefore, this paper focuses on the impact on technical trade barriers (TBT) on China's export trade, from the perspective of government and enterprises to study countermeasures. Technical barrier to trade is a trade import control. It has a duality, broadness, compliance and hidden. China is affected by internal and external causes. External causes are the protection for national interests, trade barriers, and so on. Internal factors are China's trade pattern, industrial pattern imbalance and export order disorder. For these reasons, the government should establish a good system mechanism and the enterprises should improve product quality.
\end{abstract}

\section{Keywords}

Technical Barriers to Trade, Export Trade, Economic Development

\section{Introduction}

\subsection{Research Background and Significance}

Technical barriers to trade are a kind of trade import control, protecting national security, civil, animal and plant health and safety, preventing foreign fraud and ensuring the quality of domestic products. A country (mainly developed countries) achieves the purpose of restricting imports by setting up technical standards and certification, inspection and quarantine system, technical standards for imported product. The technical barriers to trade were first explicitly stipulated in the TBT agreement when the WTO was formally established on January $1^{\text {st }} 1995$. 
After China's accession to the WTO, the volume of trade of China's exports has increased. At the same time, China is also getting more and more trade barriers, especially technical barriers to trade. In recent years, the technical trade of the export market has caused more and more influence on China's export market. According to incomplete statistics, technical barriers to trade have affected nearly two-thirds of our exports. Especially for developed countries such as Europe, America, etc., export enterprises are affected more. Heavy machinery, ship car parts, toys and lighters are all affected by the foreign TBT measures in recent years. For example, in May 2002, the European Union issued the regulation of cigarette lighters, requiring that the cheap lighter must be uninstalled. This regulation directly led to up to $80 \%$ of the domestic cigarette lighters on the verge of market risk.

Due to the WTO rules, the current tariff rate of international trade continues to decline, making foreign export products more competitive. In order to protect the development of domestic market, many developed countries are constantly looking for new ways to protect their enterprises. Among them, the TBT is adopted by developed countries to achieve the goal of trade protection for its righteousness, concealment and ease of implementation.

This article tries to explore the effect of TBT on export trade of China and understand the relevant content of TBT and try to put forward some measures and solutions to cope with TBT. Therefore, China's export enterprises can better adapt to the development of international trade.

\subsection{Literature Review}

Technical trade plays an important role in the field of international trade. Scholars from home and abroad have studied many technical barriers to trade and made great achievements.

1) The Formation of TBT

Foreign studies about TBT are earlier. For example, Barry [1] uses the perspective of transfer rent to demonstrate that lowering environmental standards would have a negative impact on all countries in the world. Keith Maskus, John Wilson [2], finds that the nature of technical barriers to trade is a trade restriction in the name of solving invalid market. It indicates that TBT restricts the healthy and sustainable development of foreign trade and add a certain hindrance to economic globalization. Xiao-HuaBao and Larry D. Qiu [3] argue that technical barriers to trade will have a negative impact on consumers' welfare, such as decrease of items, increase of price and decrease of externalities through a series of ways. X Bao and WC Chen [4] study the impact of quality standards on the quality of imports and exports. The article argues that technical barriers to trade are the measures to increase the cost of exporters, thereby reducing the competitiveness of exporters. The formulation of the minimum quality standards is an industrial policy to improve product quality standards, reduce technical barriers to trade and promote social welfare. 
Compared with foreign scholars, Chinese scholars study late. For example, You-Fu Xia [5] [6] analyses the duality of the technical barriers to trade in China, believing that the technical barriers to trade were caused by market failure and interest protection. Xiao-Qin sun and Yong $\mathrm{Wu}$ [7] suggest that technical barriers to trade have a negative impact to the exporter products' competitiveness, but has a positive effect in the long term. Hong-Mei Liu [8] points out that technical barriers to trade are dialectical. The reasonable technical barriers to trade may become the important means of regulating foreign trade, but unreasonable technical trade barriers will influence the development of foreign trade, especially foreign trade development in developing countries. At the same time, her research illuminates the government's choice of interests and promotes the construction of technical barriers to trade with the perspective of public choice.

\section{2) Relationship between technical trade barriers and foreign trade}

Anne Celia [9] believes that EU countries use the most technical barriers to trade, which reduce the export of developing and developed countries, but overall, it does not affect the total world trade volume. J Lin, P Gao [10] analyses the technical barriers to trade on Chinese export trade by using the regression analysis of statistics. The effect of technical barriers to trade on market equilibrium is estimated. S Liu, Z Li [11] analyses the effect of technical barriers to trade on trade between the United States and China. They think one-way of technical barriers to trade will have inhibition to trade and technical barriers to trade between the two sides will be good for the trade.

Domestic scholars have studied China's foreign trade with technical barriers to trade, and offered decision opinions on the relevant departments of China, especially the foreign economic and trade department.

Zong-Xian Feng [12] argues that the technical barriers to trade are the major impediment to foreign trade with China and thinks that China should set up international technical standards, inspection and quarantine standards and poisonous and harmful chemical testing standard. Jian-Xin Wang [13] argues that the technical barriers to trade are divided into short-term and long-term effects. In the short term, the technical barriers to trade have negative impact on China's foreign trade, but in the long run, the government and enterprises will establish a set of standards to adapt to the international standards and improve the technological innovation, having a positive impact on China's foreign trade. JingNing Li [14] expounds that the technical barriers to trade have a dual mechanism of combination of quantity and price control using the dynamic analysis method. Ya-Jun Zhang [15] argues that there are both positive and negative impact of technical barriers to trade. The reasonable TBTs protect the safety of the country, citizens, plants and animals while unreasonable ones would increase the cost of trade and the amount of trade disputes.

This paper analyses the positive and negative aspects of technical barriers to trade, from the perspective of government and enterprises to study countermeasures. The innovation of this paper is to analyze the proportion of positive and negative influences. The impact on technical barriers on China's export 
trade is multifaceted.

\section{The Influence of Technical Barriers to Trade on China's Export Trades}

\subsection{The Status Quo}

According to the China network ${ }^{1}$, China's trades with the European Union and the United States still have a high volume of trade. Bilateral trades between China and emerging economies (ASEAN, Africa, etc.) have performed well. The following figure shows the foreign trade volume and trade barriers, respectively, as shown in Figure 1 and Table 1.

It is easy to see from 2.1.1 and 2.1.2 that China's bilateral trade is still too dependent on European and American countries. It leads to the fact that the international trade market in our country can be easily affected by the technical barriers to trade of the United States and Europe, which has added instability to China's economic development. The good news is that China is actively devel-

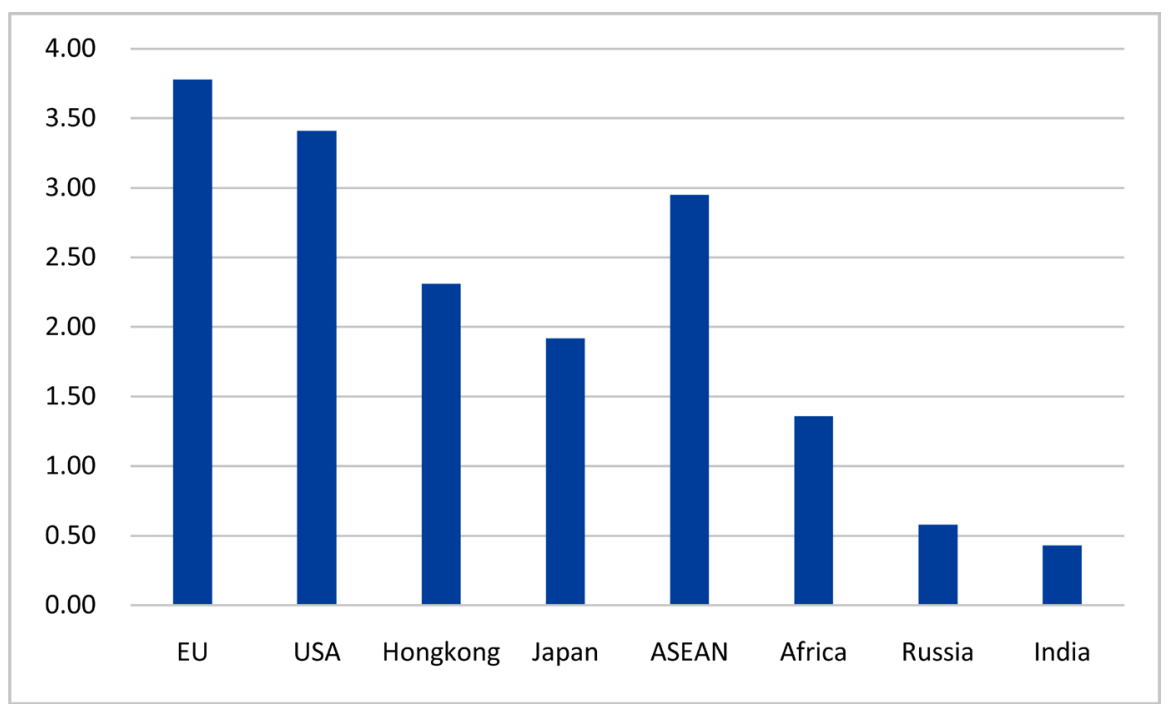

Figure 1. China’s foreign trade volume (2016).

Table 1. The quantity table of technical barriers to trade in various countries from 2012 to 2016.

\begin{tabular}{|c|c|c|c|c|c|}
\hline Country/Year & 2012 & 2013 & 2014 & 2015 & 2016 \\
\hline The European Union & 35 & 67 & 63 & 52 & 65 \\
\hline Japan & 44 & 53 & 34 & 26 & 27 \\
\hline South Korea & 37 & 34 & 58 & 46 & 47 \\
\hline The United States & 102 & 106 & 71 & 97 & 63 \\
\hline Canada & 39 & 33 & 39 & 35 & 32 \\
\hline Total & 257 & 293 & 265 & 256 & 234 \\
\hline
\end{tabular}

Source: China Business Intelligence Net http://www.askci.com/news/finance/20160520/14473118462.shtml.

${ }^{1}$ Source: China Trade Net http://finance.china.com.cn/news/20150113/2902829.shtml. 
oping towards the global market. Today, ASEAN has become the third largest bilateral trade market with China, which represents the diversification of China's trade structure.

Another big problem of China is the changing environment of the world today. From Table 2, we can see that since 1999, WTO members have increasingly used technical barriers to trade. It is not hard to see that the trend is that more and more technical barriers to trade will be adopted.

According to data onto the Ministry of Commerce (Figure 2), the annual export trade volume of 2016 is 13.84 trillion yuan, down 2\% compared with 2015 and the trade surplus is 3.35 trillion yuan. The technical barriers to trade have impact on nearly half of the domestic export enterprises. It is not optimistic that our export volume will continue to decrease from the context of the increasing technical barriers to trade.

\subsection{Empirical Data Source and Model Establishment}

The previous section analyses the present situation of technical barriers to trade. This section analysis the influence of the technical barriers to trade on Chinese exports trade. This part is to use the number of technical barriers and then make the empirical research using the trade gravity models (Table 3 ).

Table 2. New TBT numbers were added to WTO member countries from 1999 to 2015.

\begin{tabular}{|c|c|}
\hline Year & TBT numbers \\
\hline 1999 & 364 \\
\hline 2000 & 461 \\
\hline 2001 & 799 \\
\hline 2002 & 644 \\
\hline 2003 & 673 \\
\hline 2004 & 608 \\
\hline 2005 & 547 \\
\hline 2006 & 585 \\
\hline 2007 & 797 \\
\hline 2008 & 640 \\
\hline 2009 & 762 \\
\hline 2010 & 871 \\
\hline 2011 & 1038 \\
\hline 2012 & 1259 \\
\hline 2013 & 1495 \\
\hline 2014 & 1428 \\
\hline 2015 & 1215 \\
\hline 2016 & 1676 \\
\hline Total & 15862 \\
\hline
\end{tabular}

Source: WTO Net http://tbtims.wto.org/. 


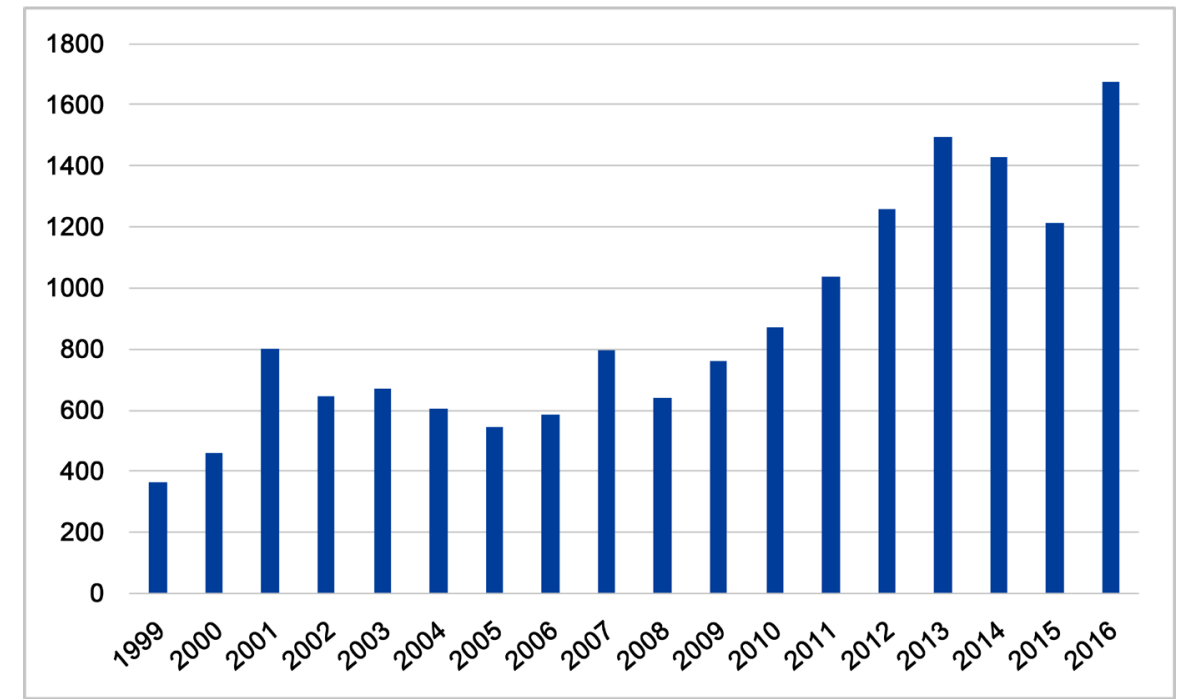

Figure 2. Data of the annual export trade.

Table 3. The meaning and source of each variable in the model.

\begin{tabular}{|c|c|c|c|}
\hline Factors & Symbol & Meaning & Source \\
\hline China's GDP & GDP & $\begin{array}{l}\text { The total GDP of China's Provinces, Municipalities directly } \\
\text { under the central government and Autonomous region }\end{array}$ & $\begin{array}{c}\text { National Bureau of Statistics } \\
\text { http://www.stats.gov.cn/tjsj/ndsj/ }\end{array}$ \\
\hline Technical barriers to trade & TBT & $\begin{array}{l}\text { The total number of technical trade barriers announced by the } \\
\text { EU, the United States and Japan }\end{array}$ & $\begin{array}{c}\text { WTO } \\
\text { http://tbtims.wto.org/ }\end{array}$ \\
\hline Foreign direct investment & FDI & $\begin{array}{l}\text { Foreign direct investment used by China's Provinces, } \\
\text { Municipalities directly under the central government and } \\
\text { Autonomous region }\end{array}$ & $\begin{array}{c}\text { National Bureau of Statistics } \\
\text { http://www.stats.gov.cn/tisj/ndsj/ }\end{array}$ \\
\hline Rate & $\mathrm{R}$ & RMB against USD (Annual average) & $\begin{array}{c}\text { National Bureau of Statistics } \\
\text { http://www.stats.gov.cn/tijsj/ndsj/ }\end{array}$ \\
\hline Fixed-asset investment & FI & $\begin{array}{l}\text { Fixed-asset investment in China's Provinces, Municipalities } \\
\text { directly under the central government and Autonomous } \\
\text { region }\end{array}$ & $\begin{array}{c}\text { National Bureau of Statistics } \\
\text { http://www.stats.gov.cn/tijs/ndsj/ }\end{array}$ \\
\hline
\end{tabular}

Factors include domestic factors (GDP, foreign direct investment, exchange rate, fixed assets investment) and foreign factors (technical trade barriers of trade);

Model: $E X_{i t}=\beta_{1} T B T_{i t}+\beta_{2} G D P_{t i}++\beta_{3} F D I_{i t}+\beta_{4} R_{\mathrm{t}}+\beta_{5} F I_{i t}+u_{i t}$;

$(\mathrm{i}=1,2, \ldots, 30 ; \mathrm{t}=1995,2006, \ldots, 2015$, i means 30 Provinces, Municipalities directly under the central government and Autonomous region, $t$ means year);

\subsection{Empirical Study Descriptions and Results}

Use STATA software to conduct empirical research, input data onto STATA software and observe the descriptive statistics, and get the following results (Table 4):

From the above, we get the mean, average, maximum and minimum of the dependent variables. The year of empirical data research was 21 years from 1995 to 2015 , covering 30 provinces, municipalities and autonomous regions of China. 
In the case of empirical analysis, this paper firstly considers the relationship between variables (positively correlated or negatively correlated). Using the PWCORR tool of STATA software to test the variables in the model, the results are as follows (Table 5):

From Table 5, export volume is positively correlated with technical barriers to trade, gross domestic product, foreign direct investment and fixed asset investment, while it is negatively correlated with the RMB exchange rate. In addition, technical barriers to trade are positively correlated with gross domestic product, foreign direct investment and fixed assets, while they are negative correlated with exchange rate.

Furthermore, this paper needs to estimate the model and makes the OLS regression analysis using REG tool. The regression sample is 630 . The regression results are as follows (Table 6):

Table 4. Descriptive statistics table of variables.

\begin{tabular}{cccccc}
\hline Variable & Obs & Mean & Std. Dev & Min & Max \\
\hline export & 630 & $66,889.13$ & $49,604.05$ & $12,451.8$ & $143,883.7$ \\
TBT & 630 & 732.3333 & 371.2412 & 256 & 1495 \\
GDP & 630 & $273,036.2$ & $20,8399.5$ & $61,339.9$ & $685,505.8$ \\
R & 630 & 754.6343 & 88.71354 & 614.28 & 831.42 \\
FDI & 630 & 725.5938 & 323.2024 & 336.23 & 1262.67 \\
FI & 630 & $167,507.4$ & $17,8087.1$ & $11,978.2$ & $561,999.8$ \\
\hline
\end{tabular}

Data source: the empirical results of STATA.

Table 5. Correlation coefficient test data table of variables.

\begin{tabular}{ccccccc}
\hline & export & TBT & GDP & R & FDI & FI \\
\hline export & 1 & & & & & \\
TBT & 0.8891 & 1 & & & & \\
GDP & 0.9666 & 0.9274 & 1 & 1 & 1 & \\
R & -0.9532 & -0.879 & -0.9723 & 0.9816 & -0.9789 & 1 \\
FDI & 0.9766 & 0.904 & 0.9933 & -0.9537 & 0.957 & 1 \\
FI & 0.9378 & 0.9164 & 0.957 & & \\
\hline
\end{tabular}

Data source: the empirical results of STATA.

Table 6. OLS regression results table.

\begin{tabular}{lllllll}
\hline export & Coef. & Std. Err. & $\mathrm{t}$ & $\mathrm{P}>\mathrm{t}$ & [95\% Conf. & Interval] \\
\hline TBT & -24.03763 & 15.50373 & -1.55 & 0.142 & -57.08305 & 9.007789 \\
GDP & 0.9280066 & 0.2438818 & 3.81 & $0.002^{\star * *}$ & 0.4081848 & 1.447828 \\
FDI & -40.17824 & 60.9806 & -0.66 & 0.520 & -170.1553 & 89.79883 \\
R & 124.8255 & 116.8945 & 1.07 & 0.302 & -124.3292 & 373.9802 \\
FI & -0.6425136 & 0.1775461 & -3.62 & $0.003^{* * *}$ & -1.020944 & -0.264083 \\
_cons & $-126,305.4$ & $107,120.7$ & -1.18 & 0.257 & $-354,627.8$ & $102,016.9$ \\
\hline
\end{tabular}

Data source: the empirical results of STATA. 


\subsection{Empirical Conclusion}

According to the empirical results, TBT's coefficient (-24.03763) is negative and the $\mathrm{P}$ value of TBT is 0.142 , indicating that the technical barriers to trade have no significant negative correlation with China's export trade. It suggests that the impact on technical barriers on China's export trade may be multifaceted, not only negative, but also partly positive.

The negative effects of technical barriers to trade are mainly:

First, trade barriers will restrict the rate of trade growth. Technical barriers to trade can increase the operating costs of enterprise. High-tech enterprises will cost more research and development money to meet the high standards and improve product quality. Then a large part of revenue will be taken up in research and development, leading to the cash flow to be affected.

Secondly, trade barriers will affect the export commodity structure of exporting countries. The technical barriers affect agricultural products more than industrial products, labor-intensive products more than capital-intensive products, developing countries more than developed countries.

Thirdly, trade barriers can easily lead to trade disputes. The seriousness of the trade contradiction between countries caused by trade barriers makes it easy for the two countries to fight a price war, which is not conducive to the development of world trade.

But the technical barriers to trade also have positive influence on the export trade, such as:

First, technical barriers to trade have changed China's trade structure, from relying on Europe and USA to ASEAN and Africa.

Secondly, technical barriers to trade have changed our policy and raised industry standards. The enterprises not only improve the ability of deal with TBT and adapt to the international trade rules, but also improve the competitiveness of export products at the same time.

\section{China's Countermeasures against TBT}

\subsection{For Government}

Government should study and understand the categories of technical barriers; establish special institutions to understand the standards and technical barriers of all countries; establish international standards and certification methods; cultivate professional talents and form a professional consulting team.

First, the government needs to study and understand the categories of technical barriers and establish special institutions to understand the standards and technical barriers of all countries. For example, National Institute of Standards and Technology in USA, investigate and research the standard of different countries, and find the solution. So China should study the TBT established by the countries all over the world. In addition, WTO has a subsidiary body which is responsible for the notification and consultation with technical regulations and qualified standards. As a member of WTO, China should understand the 
situation of other countries and make good use of preferential policies on developing countries.

Secondly, the government needs to establish standards and certification methods that meet international standards. The government should accelerate the establishment of the international standard and the law and regulation system. The government can use this to restrain unreasonable trade barriers in other countries and create fair environment for companies.

Thirdly, the government needs to train professional talents, form a professional advisory team, and help enterprises to deal with trade barriers. The first method is to establish a corresponding university and teaches a group of talented students. The second method is to looking for people who are familiar with WTO rules and trade means.

\subsection{For Enterprise}

Enterprises should understand the relevant protocols of TBT; improve the technical level and the quality of the products; develop go-out strategy; develop brand strategy and brand maintenance; tap into a diverse market.

First, the enterprises should understand the relevant protocols of TBT. Before exporting, companies should learn about the technical barriers that countries often use. Furthermore, they should also learn the trade knowledge of WTO and take advantage of the most-favoured-nation treatment to protect own rights and interests.

Secondly, the enterprises need to raise the technical level, improve the product quality, and adopt the standardization strategy. For example, electromechanical enterprises need to change the trade structure and increase the proportion of high value-added products. They can not only be a contract worker, but need to become an autonomous company with independent research and development capability, and make a large-scale autonomous production.

Thirdly, the enterprises should develop go-out strategy. The enterprises can invest abroad, make cross-border mergers and acquisitions, use the foreign company's sale channels and avoid the TBT. For example, Yaohua Glass establishes some factories in USA, hiring the citizens of the United States as employees. The local sale reduces the cost and help employment in the United States, so the government can not set up more requirements, and finally achieve a win-win situation.

Fourthly, the enterprises need to develop brand strategy and maintain brand maintenance. It is based on the upgrading of the internal quality, innovation and independent research. They will make a reputation for foreign markets and let foreign consumers trust their products.

\section{Conclusions}

Based on previous research results, this paper analyzes the relationship between technical trade barriers and China's foreign trade, and the main tasks are as fol- 
lows:

1) This paper has combed the research literature about the formation principle and trade effect of technical barriers to trade, and found the entry point of this paper and carried out the research of this paper.

2) This paper has summarized the connotation of technical barriers to trade and analyzed the forming principle of technical barriers to trade.

3) This paper has used empirical analysis to find the relationship between technical barriers to trade and China's foreign trade.

4) This paper has put forward some measures to counter the technical barriers to trade, from the perspective of government and enterprises.

Future research mainly has the following aspects:

1) Study other models of the formation of technical barriers to trade, and obtain the real reasons for the formation of them.

2) Collect more data from other countries.

\section{References}

[1] Barry, K. and Calvin, L. (1994) Denise Gray Barriers to Trade in Global Apple Markets, Fruit and Tree Nets Situation and Outlook. Economic Research Service, USDA, FTS-280, 7-14.

[2] Maskus, K. and Wilson, J. (2000) Quantifying the Impact of Technical Barriers to Trade: A Review of Past Attempts and the New Policy Context. World Bank.

[3] Bao, X. and Qiu, L.D. (2010) Do Technical Barriers to Trade Promote or Restrict Trade? Evidence from China. Asia-Pacific Journal of Accounting and Economics, 27-28.

[4] Bao, X. and Chen, W.C. (2013) The Impacts of Technical Barriers to Trade on Different Components of International Trade. Review of Development Economics, $10-15$.

[5] Xia, Y.-F. (2002) Technical Trade Barriers and Chinese Economic Development. Quality and Standardization, No. 1, 20-21.

[6] Xia, Y.-F. (2001) Technical Trade Barrier System and Contemporary International Trade. China Industrial Economy, No. 5, 14-20.

[7] Sun, X.-Q. and Wu, Y. (2006) Empirical Analysis on the Long-Term Impact of Technical Trade Barriers on China's Industrial Competitiveness-Based on the Comparative Study of the Four Industries. International Trade Issues, No. 5, 80-85.

[8] Liu, H.-M. (2013) Political Economic Analysis of Technical Barriers to Trade. Hubei People's Press, 89-95.

[9] Disdier, A.-C.E., Fontagn'e, L. and Mimouni, A. (2008) The Impact of Regulations on Agricultural Trade: Evidence from the SPS and Tbt Agreements. American Journal of Agricultural Economics, 90, 336-350. https://doi.org/10.1111/j.1467-8276.2007.01127.x

[10] Lin, J. and Gao, P. (2016) Analysis on the Effect of Technical Trade Barriers on Chinese Export Trade and Inspection and Quarantine Measures. Value Engineering, 9.

[11] Liu, S. and Li, Z. (2016) Impact of American Technical Barriers to Trade on China's Export-Based on Empirical Research with Trade Gravity Model. Journal of Industrial Technological \& Economics, 17-20. 
[12] Feng, Z.-X. (2001) International Trade Barriers in Open Economy. Economic Sciences Press, 49-66.

[13] Wang, J.-X. (2011) International Technology Trade. Gezhi Press, 33-37.

[14] Li, J.-N. and Pan, Y. (2012) The Development of International Technical Trade Barriers and Countermeasures. Chinese Business Theory, No. 17, 216-217.

[15] Zhang, Y.-J. (2013) The Comparison and Revelation of Technical Trade Barriers Abroad. Commercial Age, No. 19, 50-51.

Submit or recommend next manuscript to SCIRP and we will provide best service for you:

Accepting pre-submission inquiries through Email, Facebook, LinkedIn, Twitter, etc. A wide selection of journals (inclusive of 9 subjects, more than 200 journals) Providing 24-hour high-quality service

User-friendly online submission system

Fair and swift peer-review system

Efficient typesetting and proofreading procedure

Display of the result of downloads and visits, as well as the number of cited articles Maximum dissemination of your research work

Submit your manuscript at: http://papersubmission.scirp.org/

Or contact me@scirp.org 